JEL: M5

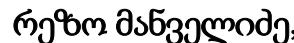

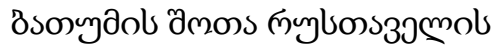

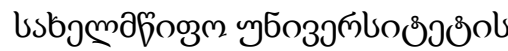

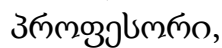

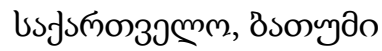

manvelidze.revaz@bsu.edu.ge orcid.org/0000-0001-9937-2020

\section{os ajlubody,}

Bsomydol gmons nuglons $39 \mathrm{mols}$

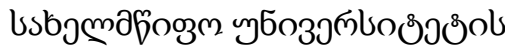

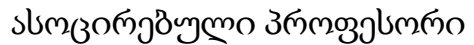
Ia.meskhidze@bsu.edu.ge orcid.org/0000-0003-1694-122X

\section{msə̃s as63эmodj,}

Bsonyaol dmons myluoss 3 m mols

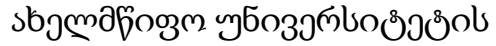

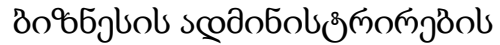

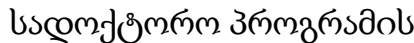

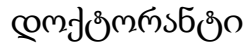
lashamanvelidze@gmail.com orcid.org/0000-0001-5631-3127

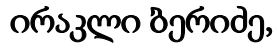

Bsonyaol dmons myluoss 3 m mols

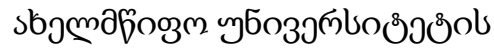

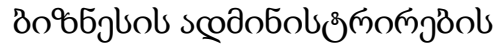

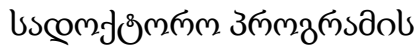

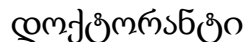
i.beridze@yahoo.com orcid.org/0000-0002-4804-7364

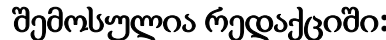

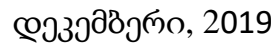

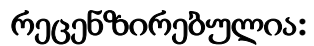

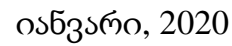

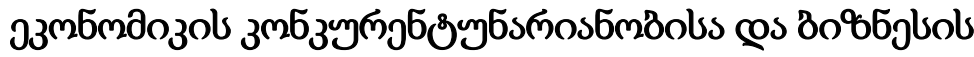

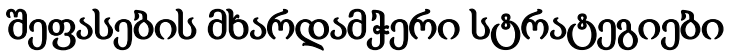

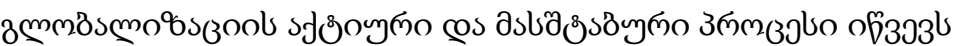

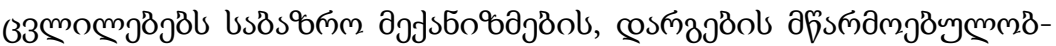

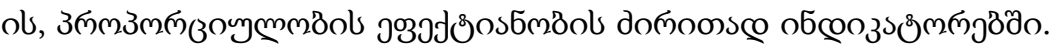

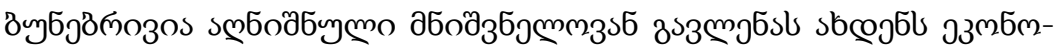

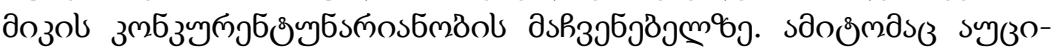

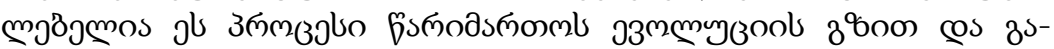

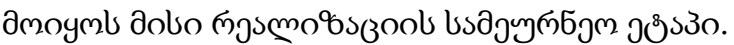

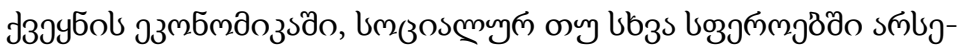

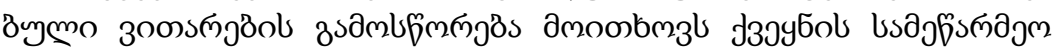

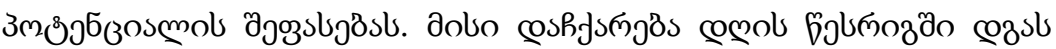

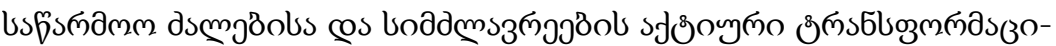

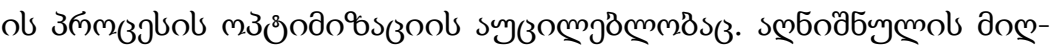

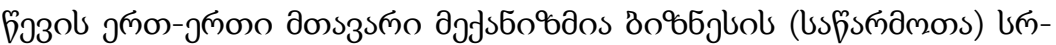

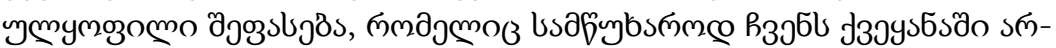

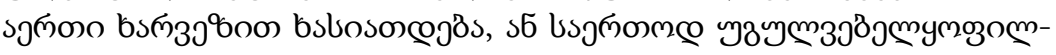
os.

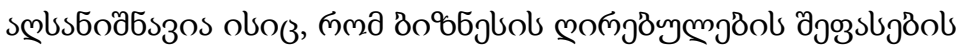

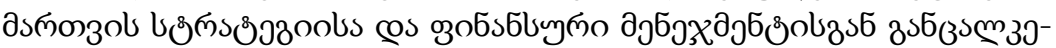

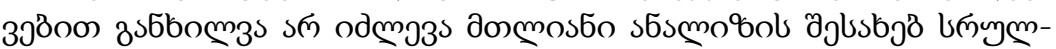

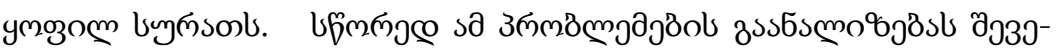

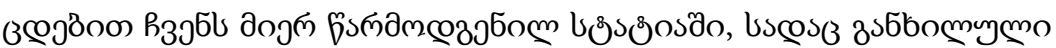

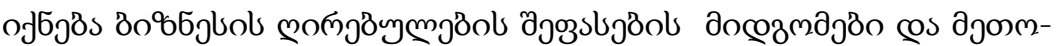

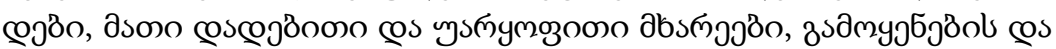

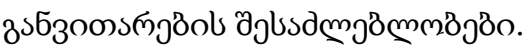

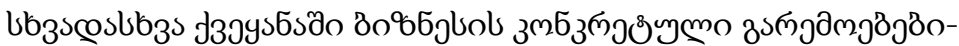

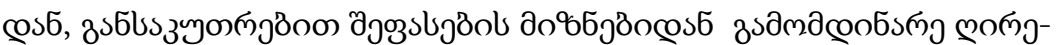

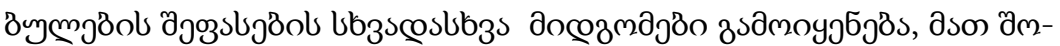

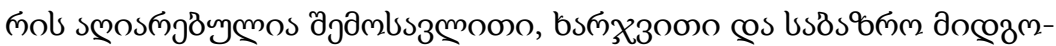

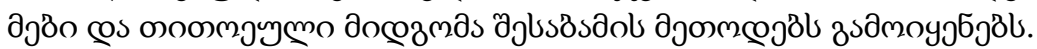

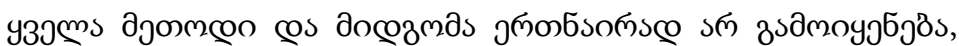

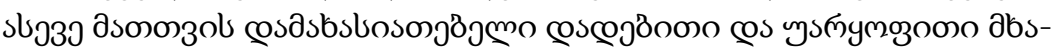

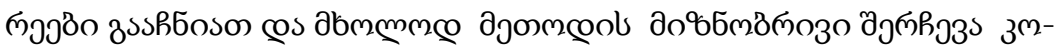

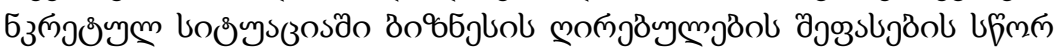

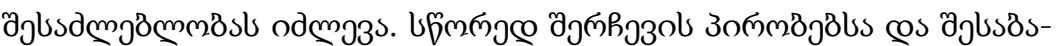

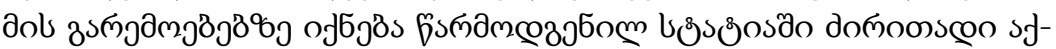
(396తీ

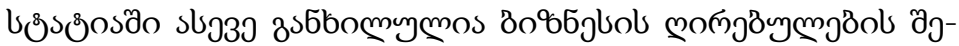

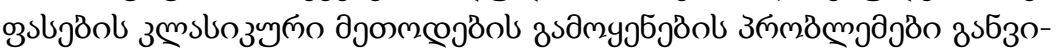

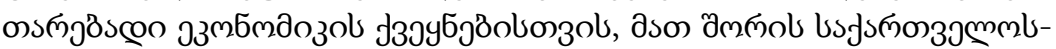

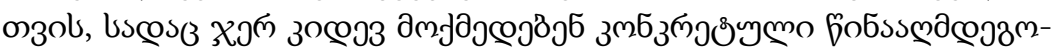

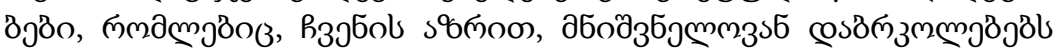

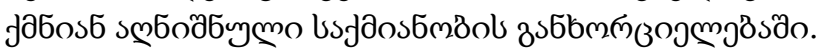

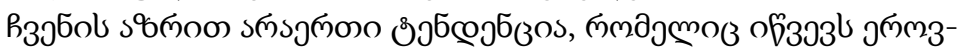

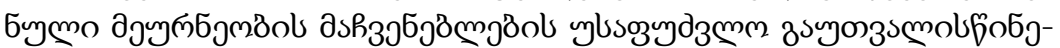

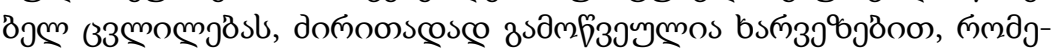

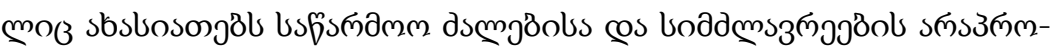

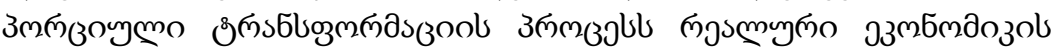

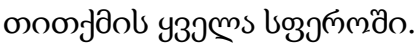




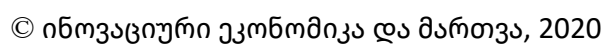

\section{JEL: M5}

\section{Rezo Manvelidze,}

Professor at Batumi Shota Rustaveli state University

Georgia, Batumi

manvelidze.revaz@bsu.edu.ge

orcid.org/0000-0001-9937-2020

\section{Ia Meskhidze,}

Associate Professor at Batumi Shota

Rustaveli State University

Georgia, Batumi

Ia.meskhidze@bsu.edu.ge

orcid.org/0000-0003-1694-122X

\section{Lasha Manvelidze,}

$\mathrm{PhD}$ student at Batumi Shota Rustaveli State University

Georgia, Batumi

lashamanvelidze@gmail.com

orcid.org/0000-0001-5631-3127

\section{Irakli Beridze,}

PhD student at Batumi Shota Rustaveli

State University

Georgia, Batumi

i.beridze@yahoo.com

orcid.org/0000-0002-4804-7364

\section{Edited by:}

Received, December, 2019

Accepted, January, 2020

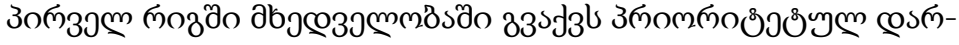

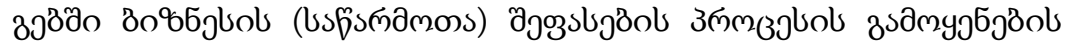

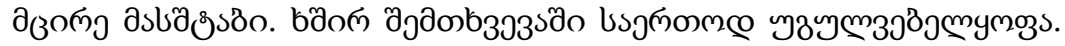

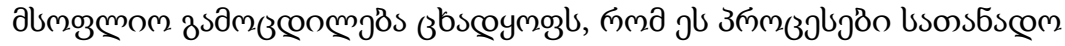

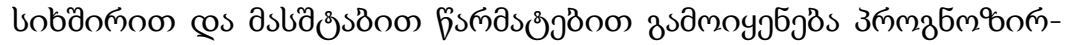

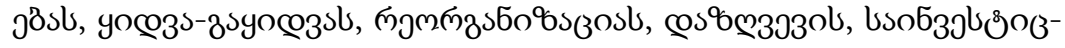

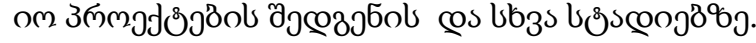

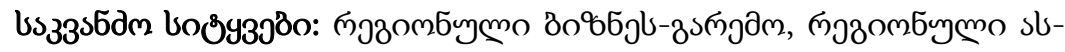

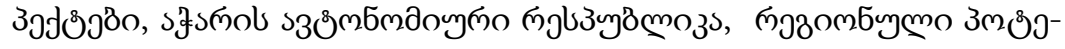

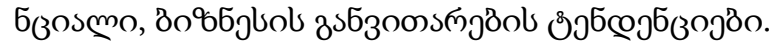

ISSN 2449-2604

\section{SOME ASPECTS OF THE EVALUATION PROCESS AND THE PECULIARITIES OF THE BUSINESS EVALUATION}

The active and large-scale process of globalization causes changes in the key indicators of market mechanisms, productivity, and proportionality. Naturally, this has a significant impact on the competitiveness of the economy. That is why it is necessary that this process is guided by evolution and to be detached the economic stage of its realization.

All country needs assessment of entrepreneur potential as it is an essential aspect of improvement of social and other fields in every country's economy. One of the main mechanisms for achieving this is the ideal assessment of the enterprises that are unfortunately characterized by many flaws or in many cases are ignored at all in our country.

In different countries according to the different circumstances, especially based on purposes of appraisal, they use individual approaches of valuation. These approaches are, for example, income, expenditure and market approaches and each of them uses relevant methodologies. Not all the methodologies and approaches are used in the same way. They have their advantages and disadvantages. The problem of classical methods of business valuation in developing countries is also discussed in the article, also for Georgia, where they still exist specific obstacles, which, in our opinion, are the obstructions in this field.

In our opinion, several trends cause an unforeseen change of national farming indicators, is mainly caused by characteristic flaws of production forces and Disproportionate transformation process in almost all areas of the real economy. On the first place, the process of business valuation in prioritized fields has a small scale or is completely ignored. International experience reveals that those processes are successfully used in prognosis, purchasing-selling, reorganization, insuring, investing and other stages.

Keywords: Business value, Value appraisal, Business market value, Valuation activities, Regional economy, Regional finance, Investment programs. 
The active and large-scale globalization process in many countries highlights the need to enhance the degree of flexibility of market mechanisms for structural change in the national economy. In developed countries, however, some sectors, including the food industry, will change significantly in scale, productivity, proportions, market segments, efficiency dynamics, and infrastructure relationships. Today, when more active global factors on the national economy to improve the competitiveness of industries, at least the minimum standards are given the maintenance processes, the agenda of the necessity of activating the directions that will strengthen and focused structural adaptation, stability, stimulating principles of market development tools. These issues will become even more pressing at the regional and municipal levels, where the institutions are similar to those of the central authority whose functions cannot even be delegated.

We believe that the country's internal, especially international, competitiveness should be driven by evolution and be distinguished by several stages. between them:

First, the effective use of local resource potential with the involvement of modern technical means. It is important to develop policies promoting traditional and innovative (industrial) sectors, with Eromell primarily focusing on protecting the internal market through an import substitution strategy. (Assuming quotas and tariffs) different approaches to tax policy shaping the investment regulatory environment and more.

Second, to support resource transformation to accelerate the development of export sectors, to encourage the introduction of international standard approaches, to support the development of relevant infrastructures.

Third, knowledge-based use of innovative technologies to support the development of economic models. Prioritize competitive advantages in investment, material provision, infrastructure development, innovative labour regulation and more.

Fourth, encouraging innovation, export potential, managerial, organizational and structural excellence, supporting the development of TNCs, cooperatives, clusters and other proven structures. Stimulation of green economy, ecosystem recovery, optimization of urban processes, development of high technology sectors.
Fifth, Moderate government policy implementation at state, regional, municipal level.

In many countries, valuation activities in modern economic science are highly valued, based on solid theoretical foundations. Business analysis and evaluation are one of the branches of economics as an academic discipline. It is a combination of economic theory and economic practice that originates in the historical past. The theoretical foundations of modern valuation work developed in parallel with the development of economic theory and are reflected in the works of such scientists and economists like Adam Smith (1723-1817), John Stuart Mill (1860-1875), Thomas Malthus (17661834), Leon Walras (1863). -1910) Alfred Marshall (1842-1924) Irving Fisher (1867-1947), John Maynard Keynes (1883-1946) and others.

In 1776, Adam Smith, in his fundamental work, "The Study of the Nature and Cause of the Wealth of Peoples," laid the groundwork for "Theory of Labor Value," which explored the essence of labour productivity growth, its role, and its importance in value creation. In 1890, Alfred Marshall for the first time in his widely accepted work „The Principles of Economic Science“ first introduced the most complete and convincing theory of value theory, which in effect overturned values. The core of this theory is that it has defined price as the magnitude of demand-supply function.

Economic theory has become modern in the fundamental work of John Maynard Keynes „The General Theory of Employment, Benefits, and Money“ (1936). Keynes defended the idea of interfering with the functioning of the government's economy to mitigate the negative effects of business cycles, economic resources and depression. His ideas formed the basis of a new school of economic thought known as Keynesian Economics. Around the same time, a broad segmentation of the "value theory" began to meet the requirements of various economic objects: assets, commercial interests, various forms of ownership, and business studies. Some economist-appraisers focus on developing a real estate value analysis and valuation system. Their work was finally summarized in a 1951 scientific paper, „The Real Estate Appraisal“, first published by "The Real Estate Appraisers" of the time. In 1934 Benjamin Grassima (Columbia Business School Professor 1894-1976) and David Dodd (University of Pennsylvania Professor 1895- 
1988) work: "Securities Analysis", which deals with business valuation issues.

In 1937, James Bombright (professor of finance at Columbia University) published a paper entitled "Property Evaluation". The author has attempted to unite the value theories of economistappraisers and financial economists. He saw that there was one common element in these theories, namely that the analyst assesses economic property rights in both cases, that is, in other words, he assesses the legal rights package and the economic advantages derived from owning the property (even though Whether this property is real or moving Whether material or non-material).

Evolutionary work has also undergone the evolution of economic theory and has been segmented into different directions. In 1981, the "International Asset Committee", which was renamed in 1994 and was named the "International Standards Committee" (IVSC). IVSC - is an international organization that unites national institutes of assessors in more than 50 countries around the world. The main objective of the IVSC is to co-ordinate the national standards of different countries and to develop a system of evaluation standards that is acceptable and effective for all member states of international cooperation. [1]

Currently, the following areas of practice are considered in valuation practice: real estate valuation, movable property valuation, intangible asset valuation, intellectual property valuation and business valuation.

There is a great practice of valuation in developed countries. In the UK, for example, assessment standards were first established in the 1970s. Professional organizations, such as the „Royal Society of Certified Real Estate Professionals“, have been instrumental in the evolution of this activity. In 1976, the society issued the so-called "The Red Book". In 1980 "The White Book". In 1996, these books were united and created a unified "Basis for Evaluation". It included several practical provisions that are actively used by professional evaluators. There are currently 18 assessment bases in the standards of this country, of which 13 are actively used. 1) Comparative method, 2) investment method, 3) best use method, 4) profit method and 5) replacement cost method. [3]

There are many Valuable societies in the US. E.g. Three are distinguished: 1) American Institute of Real Estate Appraisers; 2) The Society of Real Estate Appraisers; 3) American Society of Appraisers. Here, one of the modern concepts of equity valuation has become the measurement of surplus-value, thus actively incorporating its rate economically surplus-value - into the valuation process of companies. The method of evaluating entrepreneurial activity is also called "Balanced Set". This integrates intangible assets such as customer satisfaction with specific services, loyalty, effective staff training and more.

Similar methods are actively used in other developed countries.

The study of value-added activities and the use of advanced experience have begun in many developing countries. In this direction, both scientific-research and practical testing processes in Georgian economic science, business circles, relevant state and public organizations are actively pursued. The concept of enterprise and business, the essence of entrepreneurial and non-entrepreneurial economic activity, the categories of market and market infrastructure, the difference between the subjects and objects of valuation, and more have been acquired today.

Unfortunately, the assessment of the value of the enterprise, resources, and economic potential in the country is still considered to be disconnected from business management strategy and financial management. This is why this process does not include real-world analysis, risk assessment, development prospects, thorough and long-term priorities, potential partners and more.

Understanding the business valuation, approaches and methods used actively in different countries can be illustrated in the following chart.

Scheme №1

Basic methods of valuing an enterprise (business)

\begin{tabular}{|l|l|l|l|}
\hline Essence & Income & Expences & Market \\
\hline Approach & Income Approach & Expense Approach & Market(comparative) Approach \\
\hline Methods & 1. Discounting future & 1. Capitalization of Net & 1. Firm Value and Profit Ratio \\
& profits & Assets. & 2. The ratio between value and cash flow \\
& 2. Discounting future cash & 2. Liquidation cost & 3. Value and Gross Income Ratio \\
& flows & 3. Excess revenue & 4. Value-for-money ratio \\
& 3. Capitalize on profit & method & 5. Past trades related to company shares \\
\hline
\end{tabular}




\begin{tabular}{|l|l|l|l|}
\hline & $\begin{array}{l}\text { 4. Capitalization of cash } \\
\text { flows }\end{array}$ & $\begin{array}{l}\text { 6. Proposals related to the acquisition of the } \\
\text { company. }\end{array}$ \\
\hline
\end{tabular}

Considering both the advantages and disadvantages of these methods and approaches and grouping them according to the nature of the impact on the evaluation process is very important for the business (ente- rprise) stakeholders. We have attempted to illustrate the advantages and disadvantages of using each method scheme:

Scheme №2

Advantages and disadvantages of basic methods of valuation of an enterprise (business)

\begin{tabular}{|c|c|c|}
\hline Method & Advantages & Disadvantages \\
\hline Expences & $\begin{array}{l}\text { - takes into account the impact of manufacturing } \\
\text { factors on the value of assets; } \\
\text { - provides the opportunity to assess the level of } \\
\text { technology development; } \\
\text { - The calculations are based on actual financial and } \\
\text { accounting documents. }\end{array}$ & $\begin{array}{l}\text { - reflects past value; } \\
\text { - does not take into account the market } \\
\text { situation at the valuation date; } \\
\text { - does not take into account the prospect of } \\
\text { enterprise development; } \\
\text { - does not take into account risks; } \\
\text { - There is no link between the present and } \\
\text { future performance of the enterprise. }\end{array}$ \\
\hline Income & $\begin{array}{l}\text { - foresees a future change in revenue and } \\
\text { expenditure; } \\
\text { - takes into account the level of risk when } \\
\text { discounting; } \\
\text { - Takes into account investor interests. }\end{array}$ & $\begin{array}{l}\text { - difficulty predicting future results; } \\
\text { - possible use of several income norms, } \\
\text { which complicates decision making; } \\
\text { - Does not take into account market } \\
\text { conjuncture; } \\
\text { - Time-consuming calculations. }\end{array}$ \\
\hline $\begin{array}{l}\text { Market } \\
\text { (Comparative) }\end{array}$ & $\begin{array}{l}\text { - based on real market data; } \\
\text { - reflects existing buying and selling practices; } \\
\text { Takes into account the impact of sectoral and } \\
\text { regional factors on the share price of the enterprise. }\end{array}$ & $\begin{array}{l}\text { - Inadequately characterizes the } \\
\text { organizational, technical and financial } \\
\text { characteristics of the plant. } \\
\text { - only retrospective information is taken } \\
\text { into account; } \\
\text { - Requires a lot of correction and analysis } \\
\text { information. }\end{array}$ \\
\hline
\end{tabular}

These possible misconceptions indicate that the final methods and approaches should only be used after analyzing the purpose of the business (enterprise) evaluation and the advantages and disadvantages of the evaluation approaches and reconciling them with the expected final result.

In our country, as in many developed economies, the use of classical approaches to business (production) valuation faces many obstacles. Among them in our opinion, it is important:

- Scarce, unidentified (unspecified) databases;

- Low level of market infrastructure development;

- Securities are market underdevelopment, financial market volatility;

- Low culture of using modern complex planning and forecasting approaches;
- Low level of application of international accounting standards;

- systematic variability of business-related legislation and approaches;

- Incomplete state regulatory factors for the sustainable development of business;

- Neglecting regional factors in business development, which results in inefficient use of local manufacturing and entrepreneurial potential.

We have attempted to introduce the principle of value appraisal based on the merits of production factors and market-based approaches, in particular, to point out the disadvantages and advantages of each. Comparison of approaches to company valuation is based on different valuation principles outlined in Scheme №3.

Comparing approaches to value estimation

\begin{tabular}{|l|l|l|}
\hline $\begin{array}{l}\text { Principles of Value } \\
\text { Appraisal }\end{array}$ & Advantages & Disadvantages \\
\hline $\begin{array}{l}\text { Essence-based } \\
\text { approaches to }\end{array}$ & $\begin{array}{l}\text { - The simplicity of calculations; } \\
\text { - Confirmation of accounting data by }\end{array}$ & $\begin{array}{l}\text { - the difference between valuation and fair value; } \\
\text { - the subjectivity of evaluation; }\end{array}$ \\
\hline
\end{tabular}




\begin{tabular}{|l|l|l|}
\hline production factors & $\begin{array}{l}\text { official documents; } \\
\text { - In most cases, they prefer the } \\
\text { predictive approach of the enterprise. }\end{array}$ & $\begin{array}{l}\text { - the possibility of significant disruptions to the } \\
\text { valuation (for example, the valuation of bankruptcies } \\
\text { by rated companies) }\end{array}$ \\
\hline $\begin{array}{l}\text { Market behaviour- } \\
\text { based approaches }\end{array}$ & $\begin{array}{l}\text { - Ease of access to information; } \\
\text { - reflects the Company's fair value at } \\
\text { that date; } \\
\text { - The basic principle of the market } \\
\text { economy - demand-supply law is } \\
\text { realized. }\end{array}$ & - the possibility of speculative price changes. \\
\hline
\end{tabular}

As the comparison shows, selecting value-based approaches to value estimation often leads to misstatement of company leadership on the market place and strategic development. That's why in the valuation we consider the capitalization of the company that determines the real market value of the company more purposefully.

Together with the above-mentioned methods and approaches, it is advisable to consider the following methods of determining business value:

1. Grouping method: Comparing the value of an enterprise with a lower price; Price correction with reduction; Work on price equalization.

2. Planning: We give 3 points ( 3 cards) to a low-cost enterprise; We use independent pricing cards; Each evaluation is analyzed; Discussion is taking place; Evaluation again; The evaluation is completed after all three cards are filled.

3. Mid-term analysis: valuation of value foreseen added income.

4. Deferred Value: Evaluate in Easy Ways; Evaluate the value of contracts; Evaluate investment concerning return on.

5. Return on investment: Gross revenue divided by total cost minus 1 (expressed as a percentage)

6. Cash Analysis: Planning, Determining Revenue and Expenses by Month; Plan to get cash by the months.

7.Current value: Current value is determined by cash flow analysis, which includes the time value of money. (For example, the dollar today is more expensive or cheaper than tomorrow).

The assessment of regional economic potential is also important in that a particular area has both absolute and comparative advantages, as well as specific models of development, which first of all require the assessment of individual sectors and areas on a wide range of levels. Of course, when evaluating businesses and enterprises, analyzing the composition of such consolidated indicators as domestic regional output, quantitative indicators of production, the dynamics of the share of valueadded, the place of business in the regional product.
In the region's socio-economic development, family farms, non-market services, other than family services, play an important role. In our opinion, parameters such as total value-added, number of products and services, intermediate consumption, the volume of main income, expenses, investments, export-import, the share of own resources and so on should be considered in calculating this indicator.

The criteria for assessing the region's economic development are economic growth, its pace. We are referring to the economic growth of public value, which means that the demand of the population will be higher than it was at the baseline.

Determining the real situation and challenges in the regional economy is highly dependent on the composition of the region's socio-economic indicators, as well as on the accuracy of the factors determining economic growth and the structure of public wealth. The degree of accuracy and magnitude of these and other criteria is primarily determined by the ability of the regional economy, that is, the business and enterprise valuation process, to use optimal approaches.

Today, in many countries of the world, regional classification practices are applied in terms of growth rate, utilization of production and resource potential, hierarchical character, functional purpose, administrative features and other indicators. Naturally, such divisions primarily serve the outcome-oriented strategies of their development, including the development of regional economies, based on which the business presents precisely defined business valuation approaches and methods as a starting point for defining the key socio-economic perspective of the region [2].

Interregional, as well as regional and central government, as well as financial relations of various entities with them and adjusting to real benchmarks, implies a realistic assessment of active economic processes including business. The main aim is to clarify whether the subject (in this case the selfgovernance of local authorities and municipalities) for the Implementation of the financial basis, 
independent of financial guarantees, the quality of the local social and economic problems will ease, if not perform a different name IPO obligations [2].

In our opinion, the measures set out in this direction should take into account several key circumstances. Among them is the need to agree with academician Vladimir Papava that the choice of the model of "financial-budgetary federalism" primarily involves what functions the central government will perform and what issues it intends to delegate to local authorities [6]. We will also outline a strategic course that focuses on the effective use of local resources and capabilities, and the introduction of proven economic (enterprise, governance, organizational) models.

We believe that Georgian legislation defines the essence, purpose, objectives and scope of programs that provide funding sources such as state budget, investments, including foreign, grant, charity, foundation, municipal resources, sectoral resources and more. However, such funding requires a thorough set of successful assets, methodological and strategic standards. [8]

Effective and resolute prioritization of the aforementioned approaches is essential given that "regulation of the future economy" will have the character of a highly qualified, scientifically justified, moderate and efficient functioning of the market. Adjustment forms, methods, tools that will help establish and maintain equilibrium will be used:

A) between the real and financial sectors of the economy;

B) financial innovations and their regulatory structures;

C) between consumption, savings and investment. [5]

We believe that with such approaches the regions of Georgia can be involved in the international division of labour, employ high-tech achievements, stimulating mechanisms, and various preventives.

To further improve the valuation activities in Georgia, we consider it appropriate:

- to develop educational programs with the basics of granting relevant qualifications in the university space;

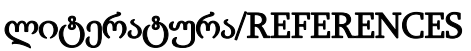

[1] Abralava A., Global-Innovative Problems of Economics and Business, Tb, 2014;

[2] Asatiani R., Asatiani S., Business Management and Global Competition, Tb, 2009;

[3] Manvelidze R., The Alternative Possibilities of Countryside Development, Kalmosani, Bt, 2017;
- Licenses and other permits issued as permits for certain activities, especially for small, micro and medium-sized businesses, are issued to legal entities and not to property companies. The said sale process does not include the sale of the right to operate. This creates significant delays for the new owner. We think a new approach is being studied;

- Buying a business would mean buying an "entered ball" on the market, that is, a new entrepreneur thinks that he will maintain his position in the market and retain his customers along with the enterprise. This is an area of relationships that should be substantiated by the notion of "business reputation". These figures should be important in determining the official value.

- Business, as well as the value of an enterprise or another material asset, must consider the processes within the business that are primarily related to the business environment. Therefore, the valuation process should analyze these factors and have a significant impact on determining value at that time;

- During assessment should take into account factors such as demand, time, revenue, risks, liquidity, constraints, demand-side ratio, strategy, customer and partner stability (length of time) and more;

- Assessment process should include the steps of and specification, such as: defining the problem, industry identification, evaluation of the object of detection, assessment plan to determine the appropriate document, information and rate analysis, analysis of market conjuncture, preemptive, and delayed accompanying indicators, assessment $\mathrm{He}$ approaches and methods of selection, preparation of assessment report, the assessment of the particulars and necessary amendment preparation;

- The active use of the results of the activities to be assessed in the planning and strategy-setting process of the country's socio-economic forecasting will be given more impetus. 
[4] Manvelidze R., For the Estimation of the Potential of Agriculture, Adjara, Bt. 1997;

[5] Meskhia I. Gellesian E., Regional Economic Policy, Tbilisi, 2012;

[6] Mekvabishvili E., Globalization-era financial crises and the Georgian economy, Tbilisi, 2018;

[7] Baratashvili E., Gechbaia B., Glonti V., Copmetitiveness of Georgian Economy: Modern Challenges. Publishing House "UNIVERSAL" Tbilisi 2012;

[8] International Standards on Assessment 2007, Georgian language edition, \# 12 (120), 2009;

[9] Chikhladze N., Gabelashvili f., Active Issues in Forming the Region's Socio-Economic Development Program", Journal of Economic Profile, \# 2, on̊ , 2007;

[10] Strovsky V.E., Simonyan A.L., "Background and Method Assessment Standpoints Business in Contemporary Conditions", Uralskogo Judgment Upper Upper Universities, №1 (33), 2014; 